Elie Cheniaux

(ㄱ) https://orcid.org/0000-0003-4769-2684

Antonio Egidio Nardi ${ }^{2}$

(- https://orcid.org/0000-0002-2152-4669

Marleide da Mota Gomes 3

O https://orcid.org/0000-0001-8889-2573

\section{What would be the psychiatric diagnosis of D. Maria I, the "mad queen"?}

\author{
Qual seria o diagnóstico psiquiátrico de D. Maria I, a "rainha louca"?
}

DOI: $10.1590 / 0047-2085000000334$

\begin{abstract}
Objective: D. Maria I, queen of Portugal, was the mother of João VI and grandmother of Pedro IV of Portugal and I of Brazil. She became the first monarch of Brazil, where she became known as "Maria, the madwoman". We aimed to try to identify the mental disorder she suffered from. Methods: We conducted a review of biographies about D. Maria I and scientific articles that discussed her case. Results: The sparse information about her mental illness strongly indicates that she had several depressive and manic episodes, which were accompanied by psychotic symptoms. Conclusion: Her probable psychiatric diagnosis is that of bipolar disorder.
\end{abstract}

KEYWORDS

Bipolar disorder, history of medicine, Portugal, Brazil.

\section{RESUMO}

Objetivo: D. Maria I, rainha de Portugal, era mãe de D. João VI e avó de D. Pedro IV de Portugal e I do Brasil. Tornou-se a primeira monarca do Brasil, onde ficou conhecida como "Maria, a louca". Nosso objetivo foi tentar identificar o transtorno mental de que ela sofria. Métodos: Realizamos uma revisão de biografias sobre D. Maria I e artigos científicos que discutiram seu caso. Resultados: A escassa informação sobre sua doença mental indica fortemente que ela teve vários episódios depressivos e maníacos, os quais foram acompanhados por sintomas psicóticos. Conclusão: Seu provável diagnóstico psiquiátrico é de transtorno bipolar.

PALAVRAS-CHAVE:

Transtorno bipolar, história da medicina, Portugal, Brasil.

\section{INTRODUCTION}

D. Maria I (Figure 1) was the mother of John VI and grandmother of Pedro IV of Portugal, who proclaimed Brazil's independence and became the first Brazilian Emperor, Pedro I'. Born in 1734, she ascended to the throne of Portugal in 1777 with the death of her father². In 1789, as the queen of Portugal, it was she who ordered the execution of Joaquim José da Silva Xavier, the "Tiradentes", one of the leaders of the Brazilian separatist movement known as "Inconfidência Mineira"1. When, in 1807, Napoleon's troops invaded Portuguese territory, D. Maria I and the entire royal family fled to Brazil. Eight years later that country ceased to be a colony of Portugal and became part of the United Kingdom of Portugal, Brazil, and Algarves. Thus, she became the first monarch of Brazil, where she died in 1816, at the age of $81^{2}$.

Still in Portugal, in 1792, D. Maria I was declared mentally insane by court physicians. Consequently, she was considered incapable of governing the country and was then replaced in public administration by her son, Prince John VI'. In Portugal, she was called "Maria, the pious one", but in Brazil, she became known as "Maria, the madwoman"3. Did Maria I suffer from a mental disorder? And what would be her diagnosis? The scientific literature on her clinical case

Received in: Dec/30/2020. Approved in: May/23/2021

1 State University of Rio de Janeiro, Rio de Janeiro, RJ, Brazil. Institute of Psychiatry of Federal University of Rio de Janeiro, Rio de Janeiro, RJ, Brazil. 2 Federal University of Rio de Janeiro, Rio de Janeiro, RJ, Brazil.

3 Laboratory of History of Psychiatry, Neurology, and Mental Health, Institute of Psychiatry, Institute of Neurology, Federal University of Rio de Janeiro, Rio de Janeiro, RJ, Brazil.

Address for correspondence: Elie Cheniaux. Av. N. Sra. Copacabana, 1066 / 1101 - 22060-002 - Rio de Janeiro, RJ, Brazil. E-mail: echeniaux@gmail.com 


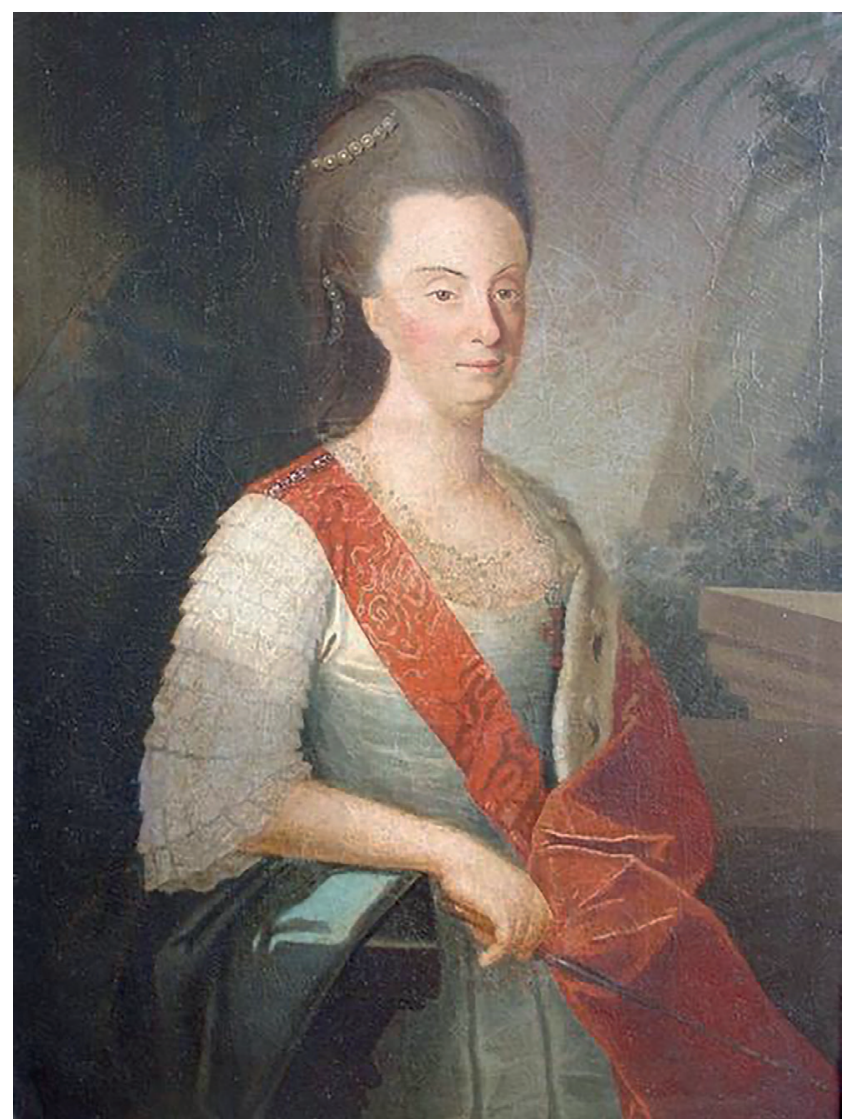

Figure 1. Portrait of Dona Maria I of Portugal (*Lisbon, Portugal, 17 December 1734 - † Rio de Janeiro, Brazil, 20 March 1816) as Queen regnant, circa, 1780, attributed to Inácio de São Paio. Public domain.

is very restricted ${ }^{4}$. There are no medical records regarding the illness of the Portuguese queen ${ }^{3}$. The available information is based mainly on reports from foreign ambassadors and visitors to Lisbon and a Portuguese foreign minister ${ }^{1,3}$. The Portuguese people, at the time, believed that the queen had been poisoned ${ }^{2}$. In a recent biography of D. Maria I, Mary Del Priore $^{2}$ speaks of "severe depression". Another biographer of the queen, Jenifer Roberts', proposes the diagnosis of bipolar disorder (BD). Peters and Willis", in turn, refer to "intermittent depression, manic episodes, and anxiety".

\section{METHODS}

In order to discuss her psychiatric diagnosis, we conducted a narrative review of the clinical case of D. Maria I. We are based on the only two biographies about the monarch that we were able to find and on some rare scientific articles that addressed her mental illness.

\section{THE CLINICAL CASE}

The chronology of the case of D. Maria I is shown in table 1.
Table 1. Chronology of the case of D. Maria I

\begin{tabular}{ll}
\hline 1734 & Was born \\
1755 & Earthquake in Lisbon \\
1758 & Távora family executions \\
1760 & Marries her uncle \\
1777 & Becomes queen of Portugal \\
1786 & Death of her husband \\
$1786-1787$ & Complaining of "melancholy" \\
1788 & Deaths of son, daughter, grandson, son-in-law, uncle and \\
& confessor \\
1791 & Onset of more severe depressive symptoms \\
1792 & Onset of manic symptoms; treated by dr. Willis and considered \\
1807 & incurable \\
1816 & Goes to Brazil \\
\hline
\end{tabular}

D. Maria I received a severe education, deeply marked by religion, and became a fervent Catholic. This at a time when the courts of the Inquisition, which condemned many for heresy, blasphemy, or witchcraft, had not yet been extinguished. As for her personality, one could say that she was an austere, sober, and discreet woman, conservative in the way she dressed².

A traumatic episode that marked his youth was the terrible earthquake, followed by a fire, which in 1755 destroyed much of Lisbon city. Three years later, she would experience another frightening experience. In 1758, her father, D. José I, the king of Portugal, on his way back from an encounter with his mistress, the young Marquess Teresa de Távora e Lorena, suffered an assassination attempt. The noble family of Távora, who enjoyed the friendship of the royal family, including D. Maria I, was held responsible for the attack. The Távora were arrested, had their property confiscated, and were cruelly killed, which was witnessed with horror by the future queen of Portugal $1^{2,3}$.

At 26, D. Maria I married D. Pedro Clemente Francisco José António, her father's brother, seventeen years older than her. The marriage was very harmonious and the two seemed very united. He never cheated on her and the couple had six children. Three of them died in childhood and two others in their youth. The remnant, D. João, later D. João VI, would become king of Portugal, before the prince regent in the impediment of his mother'.

The appearance of Maria I's psychiatric symptoms was preceded by the deaths of several people very close to her. In May 1786, she lost her husband and uncle, a victim of thrombosis'. Until the following year, she was still complaining of "melancholy", but it is not clear whether it was normal mourning or whether she had already become mentally ill. In September 1788, her eldest son, D. José, died 
of smallpox. One significant detail is that for religious reasons she had refused to inoculate her against the disease, despite the advice she had received. In November of the same year, the same illness killed Mariana Vitoria, her daughter, and soon after her newborn son and her husband, Prince Gabriel de Bourbon of Spain. That same month, the queen's confessor, Friar Ignatius of San Caetano, in whom she placed great trust, suffered a thrombosis and also died. Finally, in December 1788, D. Carlos III of Spain died, who was the father-in-law of Mariana Vitoria and uncle of D. Maria I. It was the sixth death in three years ${ }^{1-3}$, Faced with so many losses, the queen began to show symptoms of anxiety: "restlessness, [...] dry mouth, difficulty swallowing, blurred vision, tremors or heat waves," in addition to "body aches"2.

D. Maria I began to present more serious symptoms, most probably a depressive condition, in October 1791, when she was 56 years old. It was reported that she "began to plunge into great melancholy, with nocturnal anguish, interrupted sleep and a dejection of spirit"1,3. In December of the same year, it was noted that she was "very low in spirit" and that she was suffering from "melancholic reflections, the malaise in her head and a very afflicted mind"1. At that time, D. Maria I, formerly "active and exercised", became "soft and sedentary" and presented insomnia and lack of appetite ${ }^{2}$. Symptoms of this kind were recurrently present until the end of the queen's life, but based on the available information, it is not possible to estimate the frequency and duration of the episodes.

In periods when she was depressed, D. Maria I presented intense feelings of guilt, probably of a delusional nature. She felt in sin and, because of this, she refused the communion. She believed she was responsible for all the horrors of the world and had failed in her duties. She said that the deaths of her children, grandson, and loved ones were divine punishment for her sins. For her, her father's soul would suffer "eternal damnation" and her soul would also be without salvation, burning forever in the fire of Hell. It is possible that the development of these delusions is related, at least in part, to her new confessor, Monsignor José Maria de Melo, the bishop of Algarve, who repeatedly pressured her to rehabilitate and give forgiveness to the survivors of the Távora massacre, ordered by her father. Far from being benevolent and comforting, he used to preach about the horrors of Hell and covered the queen with penance ${ }^{1,2}$. At one point, D. Maria I also presented a nihilistic delusion: she thought that "she was dead and that inside she had no entrails at all"2.

From 1792 on, new symptoms appeared, apparently of a manic nature. There were reported moments of "frenzy", of "fury". Once, D. Maria I began to "vociferate and rage", frightening her family. When she was agitated, she would physically attack her servants and throw them at them ${ }^{1-3}$. On one occasion, she went to the theater and, during the performance, she had a "fit". She was then taken home and, all night long, she "shouted and moaned" and stayed "walking from side to side, pulling her hair and saying incoherent words. Sometimes her conversations were "of a low-caste nature". At other times, she was cheerful and sang, which was considered something not normal. Another story is quite suggestive of mania: "when she wanted to hear Mass at an unusual time, she was taken to the chapel, but she behaved in a very extravagant way and has since been so disturbed that she has embarrassed all those who took care of her". According to several testimonies, the queen fluctuated from a state of "lethargy" in which she seemed "dead" and could not "be animated", to another of "violent excitement", which could last several days, causing her helpers to stay up all night ${ }^{1,2}$.

Over the years, D. Maria I has received various forms of treatment, none effective. She was submitted to frequent bleeding, besides sulfurous water baths, diets, enema, and the ingestion of quinine and valerian ${ }^{1,2}$. In 1792, Dr. Francis Willis, an unlicensed English doctor, was called to Lisbon to treat the queen of Portugal ${ }^{3}$. A few years before, he had been apparently successful in treating George III, king of England, using what was called "moral treatment", a psychological, not physical treatment ${ }^{5}$. Although modern authors have formulated the porphyria diagnosis for the case of the English sovereign, there are very typical descriptions of manic and depressive episodes and it is believed that he suffered from $\mathrm{BD}^{6,7}$. The information is divergent regarding the therapeutic measures adopted by Willis in the case of $D$. Maria I. While some authors ${ }^{3}$ believe that the physician has repeated with the queen of Portugal the model of directive psychotherapy applied in George III, including the removal of stress situations, Jenifer Roberts ${ }^{1}$, biographer of D. Maria I, refers to the use of straitjackets, cold water baths, ointments, and enemas, besides vomit induction. Anyway, she did not improve and Willis considered her incurable ${ }^{4}$.

In the family of Maria I, in which many inbred marriages took place ${ }^{4}$, there were quite numerous cases of mental disorder ${ }^{3}$. Her grandfather Filipe $V$ of Spain believed that the fire consumed him from within and that this was a punishment for his sins. He oscillated between extreme lethargy and explosions of violence, sang loudly, and did not allow his nails or hair to be cut. Fernando VI, son of Filipe $V$ and uncle of Maria I, in turn, thought that he would suddenly die if he lay down. He would bang his head against the wall and attack the servants. He alternated sleepless nights with periods of complete apathy'. D Maria Vitoria, also the daughter of Felipe $V$ and mother of Maria I, often complained of "melancholy" in letters to the family². Two of Maria I's three sisters, Mariana and Dorothea, also suffered from a mental disorder, probably depression. Finally, D. João, son of the Portuguese Queen and her successor on the throne, used to present episodes of "melancholy"4. 


\section{DISCUSSION}

Despite the poverty of information about Maria I's mental illness, the descriptions of her complaints and behavior changes strongly indicate that she presented several depressive and manic episodes, which were accompanied by psychotic symptoms. Thus, using the current classification systems of psychiatry ${ }^{8}$, the probable diagnosis is that of BD.

At the time of Maria I, under the influence of the Catholic Church, mental illnesses were attributed to demonic possessions. On the other hand, among the doctors of that time, the "humoral theory" was still believed, according to which melancholy was caused by the accumulation of black bile. This was the justification for the purgative treatments and bleeding to which the Portuguese queen was subjected ${ }^{9}$. Modern concepts of what we now call BD would only be created after her death, with the French Falret and Baillarger in the 1850s, "circular madness" and "double form madness," respectively, and with the German Emil Kraepelin in 1899, "manic-depressive madness"10. And only in the twentieth century would appear effective options for the treatment of BD, such as electroconvulsive therapy, antipsychotics, antidepressants, and lithium, in addition to other mood stabilizers ${ }^{11}$.

As we have already mentioned, several close relatives of D. Maria I suffered from mental disorders, probably cases of major depressive disorder and $\mathrm{BD}$, according to the descriptions, which reinforces the hypothesis of BD for the diagnosis of the queen of Portugal. BD is associated with a high genetic load. It is estimated that between $70 \%$ and $90 \%$ of this mental disorder is inherited"1 ${ }^{11}$. Moreover, inbreeding marriages were very common in his family, and according to Mansour and collaborators ${ }^{12}$. inbreeding can be a risk factor for the development of BD.

The first episode of a mood disorder, particularly BD, often occurs after a stressful event ${ }^{13}$. This was observed in the case of D. Maria I, who became mentally ill about three years after the death of several of her relatives. In $B D$, it is more common that the first episode would be depression", what happened in the course of D. Maria I, who only in a second moment began to present manic symptoms. Finally, it is important to note the late onset of her disease, at 56 years of age, since the average age of onset of type I $\mathrm{BD}$ is 18.4 years $^{14}$ and $60 \%$ of individuals with BD become ill before the age of $21^{15}$. However, late-onset BD is not so rare: between $6 \%$ and $8 \%$ of new cases of $\mathrm{BD}$ develop after the age of $60^{16}$. Besides, between $5 \%$ and $10 \%$ of individuals with $\mathrm{BD}$ present the first episode of mania or hypomania at age over $50^{17}$. When comparing late-onset BD with earlyonset $\mathrm{BD}$, the former is more associated with brain disease, cognitive impairment, female gender, and good premorbid psychosocial functioning; and the latter, with the family history of mood disorder and atypical symptoms, such as increased weight and appetite, hypersomnia, the reactivity of mood and leaden paralysis ${ }^{16,17}$.

Although the mental illness of D. Maria I started in Portugal, it was only in Brazil that she received the nickname "Maria, the madwoman". It is true that, at the time, modern classificatory systems in psychiatry did not yet exist, however this derogatory term may have expressed feelings of hurt by the Brazilian people against the colonizers. It would be important that current history books, when referring to the monarch, contextualize the use of the term "madness", as it can be very stigmatizing for people who suffer from a mental disorder.

\section{CONCLUSIONS}

D. Maria I probably suffered from $\mathrm{BD}$, of late onset, triggered by stress events and with psychotic characteristics.

\section{INDIVIDUAL CONTRIBUTIONS}

The bibliographic search was carried out by the first and third authors. The idea of the manuscript was conceived by the last two authors. The initial version of the text was prepared by the first author and reviewed by the other authors. All three authors approved the final version of the manuscript.

\section{CONFLICTS OF INTEREST}

The authors declare no competing interests. The authors did not receive funding for this work.

\section{REFERENCES}

1. Roberts JD. Maria I - A vida notável de uma rainha louca. Alfragide: Casa das letras; 2009.

2. Del Priore MD. Maria I: As perdas e as glórias da rainha que entrou para a história como "a louca". São Paulo: Benvirá; 2019.

3. Peters TJ, Willis C. Mental health issues of Maria I of Portugal and her sisters: the contributions of the Willis family to the development of psychiatry. Hist Psychiatry. 2013;24(3):292-307.

4. Peters T, Willis C. Maria I of Portugal: Another royal psychiatric patient of Francis Willis. Br J Psychiatry. 2013;203(3):167-7.

5. Charland LC. Moral Treatment. In: The Encyclopedia of Clinical Psychology. Hoboken, NJ, USA: John Wiley \& Sons, Inc.; 2015. p. 1-4.

6. Peters T. King George III, bipolar disorder, porphyria and lessons for historians. Clin Med. 2011;11(3):261-4.

7. Pearce JMS. The Role of Dr. Francis Willis in the Madness of George III. Vol. 78, European Neurology. S. Karger AG; 2017. p. 196-9.

8. American Psychiatric Association. Diagnostic and Statistical Manual of Mental Disorders, 5th ed (DSM-5). Washington: American Psychiatric Publishing; 2013.

9. Stone MH. Healing the mind: a history of psychiatry from antiquity to the present. New York: W. W. Norton \& Company; 1997. 
10. Angst J, Marneros A. Bipolarity from ancient to modern times: Conception, birth and rebirth. J Affect Disord. 2001;67(1-3):3-19.

11. Carvalho AF, Firth J, Vieta E. Bipolar Disorder. N Engl J Med. 2020;383(1):58-66.

12. Mansour H, Klei L, Wood J, Talkowski M, Chowdari K, Fathi W, etal. Consanguinity associated with increased risk for bipolar I disorder in Egypt. Am J Med Genet B Neuropsychiatr Genet. 2009;150(6):879-85.

13. Post RM. Transduction of psychosocial stress into the neurobiology of recurrent affective disorder. Am J Psychiatry. 1992;149(8):999-1010

14. Merikangas KR, Jin R, He JP, Kessler RC, Lee S, Sampson NA, et al. Prevalence and correlates of bipolar spectrum disorder in the World Mental Health Survey Initiative. Arch Gen Psychiatry. 2011;68(3):241-51.
15. Grande I, Berk M, Birmaher B, Vieta E. Bipolar disorder. Lancet. 2016;387(10027):1561-72.

16. Azorin JM, Kaladjian A, Adida M, Fakra E. Late-onset Bipolar Illness: The Geriatric Bipolar Type VI. CNS Neurosci Ther. 2012;18(3):208-13.

17. Sajatovic M, Strejilevich SA, Gildengers AG, Dols A, Al Jurdi RK, Forester BP, et al. A report on older-age bipolar disorder from the International Society for Bipolar Disorders Task Force. Bipolar Disord. 2015;17(7):689-704. 